\title{
Effect of dietary Thais coronata shell on odour reduction and nitrogen output in rabbit farm
}

${ }^{1}$ Ozuo, U. K., ${ }^{* 1}$ Ukachukwu, S. N. and ${ }^{2}$ Odoemelam, V. U.

${ }^{\prime}$ Department of Animal Nutrition and Forage Science, Michael Okpara

University of Agriculture, Umudike, Umuahia, Abia State

${ }^{2}$ Department of Animal Science, Federal University of Technology,

Owerri, Imo State.

Abstract

*Corresponding Author: ukachukwu.Sunday@,mouau.edu.ng

This work investigated the effect of integrated forage-concentrate diets with Thais coronata as additive on reducing odour and nitrogen output in rabbit production. Thais coronata shells were thoroughly washed, dried and ground to $2 \mathrm{~mm}$ particle size. Forty-five growing rabbits were fed diets comprising 25\% forage and $75 \%$ concentrate with $0 \%, 0.25 \%, 0.50 \%$, $0.75 \%$ or $1.0 \%$ ofthe shells for two weeks in a completely randomized design (CRD) experiment. The treatments were designated T1, T2, T3, T4 and T5, respectively with 9 rabbits per dietary treatment and replicated thrice with 3 rabbits per replicate. Faeces and urine were collected and odour perception scored by 10-member panel on a 5-point scale. The mean odour perception scores of $T_{1}$ (urine $=4.02$, faeces $=3.55$ ) represented the strongest $(P<0.05)$ degree of pungency while $T_{4}$ (urine $=3.05$, faeces $\left.=2.76\right)$ gave the least $(P<0.05)$ pungent odour. Average total nitrogen yield from treatment 1 (2.93g/day) was significantly higher than those from treatments $3(2.53 \mathrm{~g} /$ day $)$ and $4(2.31 \mathrm{~g} /$ day $)$ but similar to those from treatments $2(2.74 \mathrm{~g} /$ day) and 5 (2.70g/day). Inclusion of T. coronata shell at $0.75 \%$ in a forage-concentrate (T4) diet of rabbit reduces odour in rabbit production and elicits the least yield of nitrogen.

Keywords: Thais coronata, Odour reduction, Nitrogen output, Mitigation of greenhouse gas emission, Global warming, Climate change

\section{Introduction}

Rabbits are capable of utilizing forages and fibrous feeds not digested by other monogastrics (Aduku et al., 1989) and thus represent a valuable natural resource for meeting future increases in national and international protein supply (Guzman et al., 2013). Use of forages especially tropical species encourages production of methane and other greenhouse gases (Archimedes et al., 2013; Rira et al., 2013). Concerns for increase in greenhouse gas emissions into the environment and their potential effects on global warming have aroused interest in developing production systems which reduce gas emissions without compromising animal productivity. Decrease in the dietary forage:concentrate ratio (that is, increase in the proportion of concentrates) in livestock diets have been reported to lower enteric methane (Bayat et al., 2013; Tapio et al., 2013). Also, manipulation of the caecal microbes and microbial fermentation through the use of feed additives is another promising approach (Alluwong et al., 2011; Islam et al., 2005). In fact, feed additives such as Thais coronata have been incorporated in broiler diets with positive odour reduction effects (Ukachukwu et al., 2013). Therefore, an integrated approach which strikes a balance between forage:concentrate ratios and concentrate fortification with Thais coronata as additive will go a long way in reducing odour and nitrogen output without 
compromising the productivity of rabbits. This has formed the basis for this work.

\section{Materials and methods}

Thais coronata shells were obtained from a local market in Uyo, Akwa Ibom State of Nigeria. The shells were thoroughly washed with warm water, rinsed with distilled water, air dried for 3 days and further dried in an oven at $110^{\circ} \mathrm{C}$ until constant weight was attained. Thereafter, they were crushed into fine particles to achieve homogeneity; then sieved using a $2 \mathrm{~mm}$ mesh to remove the coarser particles. In a feeding trial, 45 growing rabbits were fed diets comprising 25\% forage and $75 \%$ concentrate fortified with graded levels $(0 \%, 0.25 \%, 0.50 \%, 0.75 \%$ and $1.0 \%)$ of Thais coronata as T1, T2, T3, T4 and T5, respectively for two weeks in a completely randomized design (CRD) experiment. Each dietary treatment comprised 9 rabbits replicated thrice with 3 rabbits/replicate. Faecal and urine sample collection and perception scoring were done on the $5^{\text {th }}, 6^{\text {th }}$ and $7^{\text {th }}$ day and also on the $12^{\text {th }}, 13^{\text {th }}$ and $14^{\text {th }}$ day of the experimental period. The samples were stored in a deep- freezer until the time of nitrogen analysis. Perception scoring of the degree of pungency of faecal and urine odour were scored by 10 panelists on a 5 point scale namely; very strongly pungent, strongly pungent, moderately pungent, weakly pungent, and very weakly pungent, and rated 5, 4, 3, 2 and 1, respectively. Data collected were subjected to analysis of variance (ANOVA) in CRD, separating significant means by Duncan's new multiple range test using SPSS (2007) computer package.

\section{Results \\ Reduction of urine odour}

The degrees of pungency from the urine of rabbits fed forage plus concentrate diets fortified with graded levels of Thais coronata shells are presented in Table 1. There were significant $(\mathrm{P}<0.05)$ differences among treatments in the degree of pungency from the rabbit urine. In week 1 , the degree of pungency of urine from treatment 1 (4.10) was significantly $(\mathrm{P}<$ $0.05)$ stronger than those from the other treatments while T2 (3.53), T3 (3.17), T4 (3.07) and T5 (3.53) were similar (P> $0.05)$.

In week 2, urine odour from treatment 1 (3.93) was significantly stronger than urine from other treatments, though odour from other treatments were similar. The mean scores from weeks 1 and 2 revealed that the treatment without dietary inclusion of $T$. coronata generated the strongest $(\mathrm{P}<$ 0.05 ) degree of pungency while $T_{4}$ fortified with $0.75 \%$ dietary inclusion of $T$. coronata generated the least $(\mathrm{P}<0.05)$ pungent odour. This strongly indicates that inclusion of $T$. coronata shells in rabbit diets reduces the degree of pungency in their urine, with $0.75 \%$ inclusion level exhibiting the greatest ability to reduce odour. This result was in line with the result of Ukachukwu et al. (2013) who concluded that non activated form of $T$. coronata at $0.05 \%$ level of inclusion gave the highest odour reduction effect.

Table 1: Degree of $p$ ungency from urine of rabbits fed forage plus concentrate diet fortified with graded levels of Thais coronata shells

\begin{tabular}{lllllll}
\hline & $\mathbf{T}_{\mathbf{1}}$ & $\mathbf{T}_{\mathbf{2}}$ & $\mathbf{T}_{\mathbf{3}}$ & $\mathbf{T}_{\mathbf{4}}$ & $\mathbf{T}_{\mathbf{5}}$ & $\mathbf{S E M}$ \\
Degree of pungency & $\mathbf{( 0 \% )}$ & $\mathbf{( 0 . 2 5 \% )}$ & $\mathbf{( 0 . 5 0 \% )}$ & $\mathbf{( 0 . 7 5 \% )}$ & $\mathbf{( 1 . 0 \% )}$ & \\
\hline Week 1 & $4.10^{\mathrm{a}}$ & $3.53^{\mathrm{b}}$ & $3.17^{\mathrm{b}}$ & $3.07^{\mathrm{b}}$ & $3.53^{\mathrm{b}}$ & $0.09^{*}$ \\
Week 2 & $3.93^{\mathrm{a}}$ & $2.98^{\mathrm{b}}$ & $3.40^{\mathrm{ab}}$ & $3.03^{\mathrm{ab}}$ & $3.43^{\mathrm{ab}}$ & $0.08^{*}$ \\
Mean & $4.02^{\mathrm{a}}$ & $3.26^{\mathrm{bc}}$ & $3.29^{\mathrm{bc}}$ & $3.05^{\mathrm{c}}$ & $3.48^{\mathrm{ab}}$ & $0.06^{*}$ \\
\% Reduction & 0.00 & 18.66 & 18.16 & 24.13 & 13.43 & \\
\hline abcd: means along the same row with same superscripts are not significantly different (p>0.05) \\
*= significant; ns= not significant; SEM= Standard Error of Mean
\end{tabular}




\section{Reduction offaecal odour}

Table 2 shows the faecal odour reducing effect of diets fortified with $T$. coronata shells. The result revealed that significant differences $(\mathrm{P}<0.05)$ existed among dietary treatments on the degree of pungency of the faecal samples. Treatment 1 gave the strongest $(\mathrm{P}<0.05)$ degree of pungency in weeks 1 and 2, while treatment 4 gave the least degree of pungency. In week 1 , treatment 1 (3.50) was statistically similar $(\mathrm{P}>0.05)$ to $\mathrm{T} 2$ (3.30) and T5 (3.33) but differed significantly $(\mathrm{P}<0.05)$ from $\mathrm{T} 3$ (2.83) and T4 (2.90).
However, as intake of the diets extended from week 1 to 2 , the faecal odour from treatment 1 became significantly $(\mathrm{P}<0.05)$ stronger than all other treatments. It is obvious from the mean degree of pungency that treatment 4 (2.73) released the least pungent odour while treatment 1 gave the strongest odour (3.55) from the faeces. There were similar trends in faecal and urine odours produced. This suggests that fortifying rabbit diets with $T$. coronata shells has a strong affinity to reducing odour emanating from both urine and faeces of rabbits. This agreed with the findings of Islam et al. (2005) in a similar study.

Table 2: Degree of pungency from faeces of rabbits fed forage plus concentrate diet fortified with graded levels of Thais coronata shells

\begin{tabular}{lllllll}
\hline & $\mathbf{T}_{\mathbf{1}}$ & $\mathbf{T}_{\mathbf{2}}$ & $\mathbf{T}_{\mathbf{3}}$ & $\mathbf{T}_{\mathbf{4}}$ & $\mathbf{T}_{\mathbf{5}}$ & SEM \\
Degree of pungency & $\mathbf{( 0 \% )}$ & $\mathbf{( 0 . 2 5 \% )}$ & $\mathbf{( 0 . 5 0 \% )}$ & $\mathbf{( 0 . 7 5 \% )}$ & $\mathbf{( 1 . 0 \% )}$ & \\
\hline Week 1 & $3.50^{\mathrm{a}}$ & $3.30^{\mathrm{ab}}$ & $2.83^{\mathrm{b}}$ & $2.90^{\mathrm{b}}$ & $3.33^{\mathrm{ab}}$ & $0.08^{*}$ \\
Week 2 & $3.59^{\mathrm{a}}$ & $2.76^{\mathrm{b}}$ & $2.83^{\mathrm{b}}$ & $2.61^{\mathrm{b}}$ & $2.69^{\mathrm{b}}$ & $0.09^{*}$ \\
Mean & $3.55^{\mathrm{a}}$ & $3.03^{\mathrm{b}}$ & $2.83^{\mathrm{b}}$ & $2.76^{\mathrm{c}}$ & $3.01^{\mathrm{b}}$ & $0.06^{*}$ \\
\% Reduction & 0.00 & 14.09 & 20.28 & 23.10 & 14.93 & \\
\hline \multicolumn{2}{l}{ abcd: means along the same row with same superscripts are not significantly different (p>0.05) } \\
*= significant; ns= not significant; SEM= Standard Error of Mean
\end{tabular}

\section{Nitrogen output from rabbit excreta}

The urinary and faecal Nitrogen yields of rabbits fed forage-concentrate diets fortified with graded levels of $T$. coronata are shown in Table 3. There were no significant differences $(\mathrm{P}<0.05)$ in urine nitrogen yield from all the treatments. However, yields from treatments 1 $(0.20 \mathrm{~g} /$ day $)$ and $5(0.18 \mathrm{~g} /$ day $)$ were numerically higher while that of treatment 4 $(0.14 \mathrm{~g} / \mathrm{d})$ was the lowest. Faecal nitrogen yield from $T_{1}(2.73 \mathrm{~g} / \mathrm{d})$ was significantly higher than those from $\mathrm{T}_{3}(2.38 \mathrm{~g} / \mathrm{d})$ and $\mathrm{T}_{4}$ (2.17g/d) but similar $(\mathrm{P}>0.05)$ to those from $\mathrm{T}_{2}(2.59 \mathrm{~g} / \mathrm{d})$ and $\mathrm{T}_{5}(2.52 \mathrm{~g} / \mathrm{d})$. The total nitrogen followed the same trend with that of the faeces revealing that treatment 1 with no inclusion of $T$. coronata voided the highest quantity of nitrogen in urine and faeces, while treatment 4 containing $0.75 \%$ level of $T$. coronata yielded the least quantity of nitrogen. It has been shown that certain feed additives may reduce gaseous emissions modifying the gastrointestinal environment and the faecal chemical composition (Dinuccio et al., 2013).

Table 3: Nitrogen yield from urine and faeces of rabbits fed forage plus concentrate diet fortified with graded levels of Thais coronata

\begin{tabular}{lllllll}
\hline & $\mathbf{T}_{\mathbf{1}}$ & $\mathbf{T}_{\mathbf{2}}$ & $\mathbf{T}_{\mathbf{3}}$ & $\mathbf{T}_{\mathbf{4}}$ & $\mathbf{T}_{\mathbf{5}}$ & $\mathbf{S E M}$ \\
& $\mathbf{( 0 . 0 0 \% )}$ & $\mathbf{( 0 . 2 5 \% )}$ & $\mathbf{( 0 . 5 0 \% )}$ & $\mathbf{( 0 . 7 5 \% )}$ & $\mathbf{( 1 . 0 0 \% )}$ & \\
\hline Urinary N (g/d) & $0.20^{\mathrm{a}}$ & $0.15^{\mathrm{ab}}$ & $0.15^{\mathrm{ab}}$ & $0.14^{\mathrm{ab}}$ & $0.18^{\mathrm{a}}$ & $0.02^{*}$ \\
Faecal N (g/d) & $2.73^{\mathrm{a}}$ & $2.59^{\mathrm{ab}}$ & $2.38^{\mathrm{b}}$ & $2.17^{\mathrm{b}}$ & $2.52^{\mathrm{ab}}$ & $0.07^{*}$ \\
Total N (g/d) & $2.93^{\mathrm{a}}$ & $2.74^{\mathrm{ab}}$ & $2.53^{\mathrm{b}}$ & $2.31^{\mathrm{b}}$ & $2.70^{\mathrm{ab}}$ & $0.07^{*}$ \\
\% Reduction & 0.00 & 6.49 & 13.65 & 21.16 & 7.85 & - \\
\hline
\end{tabular}

abcd: means along the same row with same superscripts are not significantly different $(\mathrm{p}>0.05)$

*= significant, ns= not significant, $\mathrm{SEM}=$ Standard Error of Mean 


\section{Conclusion}

Fortifying rabbit diets with Thais coronata shells at $0.75 \%$ inclusion level decreased the degree of pungency and nitrogen content of urine and faeces of rabbits.

\section{References}

Aduku, A. O., Dim, N. I. and Hassan, W. 1989. Tropical Forage Studies with Rabbits. Journal of Applied Rabbit Research 12(2): 12-21

Alluwong, T., Wuyep, P. A. and Allm, L. 2011. Livestock Environment Interactions: Methane emissions from ruminants. African Journal of Biotecnology 10: 1265-1269.

Archimede, H., Rira, M., Eugene, M., Morgavi, D. P., Anais, C., Periacarpin, F., Calif, B., Martin, C., Marie-Magdeleine, C. and Doreau, M. 2013. Intake, total tract digestibility and methane emission of Texel and Blackbelly sheep fed C4 and $\mathrm{C} 3$ grasses tested simultaneously in a temperate and a tropical area. Advances in Animal Biosciences 4(2):284.

Bayat, A. R., Vento, L, Stefanski, T., Tapio, I., Kairenius, P., Leskinen, H. M., Vikki, L. and Shingfield, K. J. 2013. Advances in Animal Biosciences 4(2):274.

Dinuccio E, Biagini D, Rosato R, Balsari P, Lazzaroni C. and Montoneri E. 2013. Use of acid soluble bio-organic substances extract as rabbits feed additive to reduce manure gases emission during storage. Advances in Animal Biosciences 4(2): 515 .

Guzman, C., Kentler, C., Emmerling, M., Franks, A. and Frankel, T. 2013. Succession of microorganisms in the developing rumen of young dairy calves. Advances in Animal Biosciences 4(2):303.
Islam, K. M. S., Schuhmacher, A. and Gropp, J. M. 2005. Humic acid substances in animal agriculture. Pakistan Journal of Nutrition 4: 126 134.

Rira, M, Morgavi D. P, Popova M, Marie-Magdeleine C, SilouEtienne T, Archimede $H$. and Doreau M. 2013. Ruminal methanogen population is enhanced by tropical environment. Advances in Animal Biosciences 4(2):341.

SPSS. 2007. Statistical Package for the Social Sciences (SPSS) 16.0 for Windows 2007

Tapio, I., Blasco, L., Ventto, L., Kahala, M., Shingfield, K. J., Negusssie, E. and Vikki, J. 2013. Effect of dietary forage to concentrate ratio and sunflower oil supplements on ruminal microbial communities in lactating dairy cows. Advances in Animal Biosciences 4(2): 474.

Ukachukwu, S. N., Odoemelam, V. U., Kanu, A. U. and Nwogbugbo, I. 2013. Can dietary Thais coronata-a sea food waste control odour in a poultry house? Advances in Animal Biosciences 4(2): 301.

Received: $10^{\text {th }}$ November, 2017 Accepted: $19^{\text {th }}$ February, 2018 